\title{
THE POSSIBILITY OF CONTROLLING SCLEROTIUM ROLFSII ON SOYBEAN (GLYCINE MAX) USING TRICHODERMA AND TEBUCONAZOLE*)
}

\author{
OKKYS. DHARMAPUTRA \\ Department of Biology, Faculty of Mathematics \\ and Natural Sciences, Bogor Agricultural University; and \\ SEAMEO BIOTROP, P.O. Box 116, Bogor, Indonesia
}

and

INARETNOWATI

SEAMEO BIOTROP, P.O. Box 116, Bogor, Indonesia

\begin{abstract}
The possibility of controlling S. rolfsii on soybean (Glycine max) var. Rinjani using T. aureoviride and Tebuconazole under field conditions was studied. The experiment was conducted at the experimental plot of SEAMEO BIOTROP.

The pathogen was mixed with the soil ( $2 \mathrm{~kg} / \mathrm{plot}) 4$ days before the inoculation of the antagonist $(2.25$ $\mathrm{kg} / \mathrm{plot})$. The measurement of each plot was $2.5 \times 6 \mathrm{~m}^{2}$. N, P and K (120 kg/ha) were applied at the same day with the inoculation of the pathogen.

Soybean seeds were planted 7 days after the inoculation of the antagonist. The distance between plants and between plots were 20 and $40 \mathrm{~cm}$, respectively.

The fungicide at concentration of $100 \mathrm{~g} / \mathrm{ha}$ (in vitro concentration) and $210 \mathrm{~g} / \mathrm{ha}$ (field or recommended concentration) were applied using 2 methods, i.e. 1) spraying on the planting hole at the same day as the planting of soybean seeds, and 2) spraying on the soil surrounding the plants 7 days after planting. Soils that were neither inoculated with the antagonist nor the fungicide were used as controls. Three replications (3 plots) were used for each treatment (including the control).

The results showed that the inoculation of the antagonist, the concentrations of the fungicide, and time of application gave very significant differences in the percentages of the plants infected by the pathogen and significant differences in seed production; while the interaction between the inoculation of the antagonist and the concentrations of the fungicide, between the concentrations of the fungicide and the time of application, and between the inoculation of the antagonist, the concentrations of the fungicide and the time of application did not give significant differences either in the percentages of the plants infected by the pathogen or seed production.

The percentage of plants infected by the pathogen was lower on soil inoculated with the antagonist (31.6\%) than on soil not inoculated with the antagonist (52.9\%).

The percentage of plants infected by the pathogen was lower on soil treated with the fungicide either at in vitro concentration (37.5\%) or at field concentration (37.4\%) than on the soil not treated
\end{abstract}

\footnotetext{
*) A part of research funded by the Government of Indonesia FY 1991/1992 18
} 
Possibility of controlling Sclerotium rolfsii on soybean - Okky S. Dharmaputra and Ina Retnowati

with the fungicide (61.5\%). Nevertheless, based on statistical analysis, the fungicide at in vitro concentration was not significantly different from that at field concentration.

The percentage of plants infected by the pathogen on the soil sprayed with the fungicide at the same day of seed planting was lower $(30.5 \%)$ than sprayed 7 days after planting (44.4\%).

The seed production on the soil inoculated with the antagonist $(1893.3 \mathrm{~kg} / \mathrm{ha})$ was higher than on the soil not inoculated with the antagonist $(1465.7 \mathrm{~kg} / \mathrm{ha})$.

The production on the soil sprayed with the fungicide either at in vitro $(1758.0 \mathrm{~kg} / \mathrm{ha})$ or at field concentration $(1817.1 \mathrm{~kg} / \mathrm{ha}$ ) was higher than on the soil not sprayed with the fungicide $(1247.2 \mathrm{~kg} / \mathrm{ha})$.

The production on the soil sprayed with the fungicide at the same day of seed planting $(2010.9 \mathrm{~kg} / \mathrm{ha})$ was higher than sprayed 7 days after planting $(1564.2 \mathrm{~kg} / \mathrm{ha})$.

The combination between the inoculation of the antagonist and the fungicide application at in vitro concentration at the same day of seed planting gave higher seed production $(2391.2 \mathrm{~kg} / \mathrm{ha})$ than the inoculation of the antagonist $(1711.7 \mathrm{~kg} / \mathrm{ha})$ or the fungicide application either at in vitro concentration $(1771.9 \mathrm{~kg} / \mathrm{ha})$ or at field concentration (1939.1 kg/ha) at the same day of seed planting. However, based on statistical analysis, the interaction among the three treatments (the antagonist, the concentrations of the fungicide, and the time of application) was not significantly different.

Keywords: Sclerotium rolfsii, Glycine max, Trichoderma, Tebuconazole, Antagonist

\section{INTRODUCTION}

Sclerotium rolfsii is a soil-borne fungal pathogen that can cause root rot and damping-off of crops, among others, soybean (Glycine max) (Agrios 1988).

One of the control methods of the pathogen is by using antagonistic fungi (Cook and Baker 1983).

Some soil fungi especially Trichoderma have been reported to be potential biocontrol agents of soil-borne fungal pathogens.

According to Upadhyay and Mukhopadhyay (1986) T. harzianum was able to control the disease of sugarbeet seedlings as high as $88 \%$ under greenhouse conditions. Under field conditions, integration of PCNB (Pentachloronitro-benzene) and T. harzianum significantly reduced the incidence of Sclerotium root rot (76\% disease control) and increased the root, green foliage and sucrose yield per ha.

Cole and Zvenyika (1988) reported that $T$. harzianum integrated with Triadimenol fungicide enhanced disease control in tobacco caused by other soil-borne fungal pathogens, i.e. Rhizoctonia solani and Fusarium solani.

Under greenhouse conditions, four strains of T. harzianum suppressed damping-off of snapbean caused by S. rolfsii (Papavizas and Lewis 1989).

Tebuconazole (Folicur $250 \mathrm{EC}$ ) is a fungicide that can control the pathogen (Bayer 1990).

The objective of the study is to determine the effect of Trichoderma combined with Tebuconazole to control S. rolfsii on soybean. 


\section{MATERIALS AND METHODS}

This research was conducted at the experimental plot of BIOTROP, Bogor, Indonesia. The soil type is latosol $(\mathrm{pH} \pm 5)$.

\section{Soybean variety, isolates of $S$. rolfsii and Trichodernna, and fungicide}

S. rolfsii isolate BIO-1 and soybean variety Rinjani which was the most susceptible variety to the pathogen, were used in this study (Dharmaputra and Retnowati 1992).

T. aureoviride BIO-5 was used as antagonist because it caused the highest percentage of inhibition to the pathogen on Potato Dextrose Agar (PDA) of $\mathrm{pH} 5$ (Dharmaputra and Retnowati 1992).

Tebuconazole was used as a fungicide to control the pathogen (Bayer 1990).

\section{Preparation of pathogen and antagonist inocula}

Inoculum of the pathogen was prepared based on Riker and Riker (1936), while the inoculum of the antagonist was based on Dharmaputra and Suwandi (1989).

For the preparation of the inoculum of the pathogen, a mixture of sand : corn : water $(2: 2: 3)$ was put in plastic bags $(2.5 \mathrm{~kg} / \mathrm{bag})$, sterilized in an autoclave for $1 \mathrm{~h}$, and then incubated at room temperature for one night.

For the preparation of the inoculum of the antagonist, a mixture of sand : husk : water $(2: 4: 5)$ was treated in the same manner as the preparation of the pathogen's inoculum.

Five pieces of the pure cultures $(5 \mathrm{~mm}$ in diameter each) of the pathogen and the antagonist ( 3 days old on PDA) were grown on each medium. They were then incubated at $28{ }^{\circ} \mathrm{C}$ for 7 days.

\section{Inoculation of the pathogen and the antagonist, application of the fungicide, and planting of soybean}

The pathogen was inoculated 4 days before the inoculation of the antagonist. It was mixed homogeneously on the surface of the soil in each plot $\left(2.5 \times 6 \mathrm{~m}^{2}\right)$. The inocula of the pathogen and the antagonist were 2 and $2.25 \mathrm{~kg} / \mathrm{plot}$, respectively.

$\mathrm{N}, \mathrm{P}$ and $\mathrm{K}(120 \mathrm{~kg} / \mathrm{ha})$ were given at the same day as the inoculation of the pathogen.

Soybean seeds were planted 7 days after the inoculation of the antagonist (AIA). The distance between plants and between plots were 20 and $40 \mathrm{~cm}$, respectively. 
Tebuconazole at concentrations of $100 \mathrm{~g} / \mathrm{ha}$ (in vitro concentration) and $210 \mathrm{~g} / \mathrm{ha}$ (field concentration) were applied using 2 methods:

a) spraying in the planting hole at the same day as planting of soybean seeds

b) spraying on the soil surrounding the plants (7 days after planting).

Soils that were neither inoculated with the antagonist nor the fungicide were used as controls.

Three replications (3 plots) were used for each treatment (including the control).

Observation of the percentage of infected plants was carried out 14 days after planting (DAP), and of the soybean production at 90 DAP.

Factorial in Randomized Completely Block Design (RCBD) was used in this study consisting of 3 factors: a) the antagonist (not inoculated and inoculated with T. aureoviride BIO-5), b) the concentration of Tebuconazole $(0,100$ and $210 \mathrm{~g} / \mathrm{ha})$, and c) the time of Tebuconazole application.

\section{RESULTS AND DISCUSSION}

\section{Percentage of plants infected by the pathogen}

Analysis of variance showed that the inoculation of the antagonist and the concentrations of the fungicide gave very significant differences in the percentage of plants infected by the pathogen; the time of fungicide application gave significant difference. The interaction between the inoculation of the antagonist and the concentrations of the fungicide; the concentrations of the fungicide and the time of fungicide application; among the inoculations of the antagonist, the concentrations of the fungicide and the time of fungicide application did not give any significant difference (Table 1).

Infected and non-infected plants at $14 \mathrm{DAP}$ are presented in Figure 1. The percentage of plants infected by the pathogen was lower (34.1\%) and significantly different on the soils inoculated with the antagonist than on the soils not inoculated with the antagonist (56.8\%) (Table 2). The percentage of plants infected by the pathogen was lower on the soil sprayed with the fungicide either in vitro $(37.5 \%)$ or field $(37.4 \%)$ concentration compared to the soil not sprayed with the fungicide (61.5\%). Nevertheless, the fungicide application at in vitro concentration did not differ significantly from field concentration.

The percentage of plants infected by the pathogen was lower and significantly different when the fungicide was applied at the same day as the planting of soybean 
BIOTROPIA No. 7, 1994

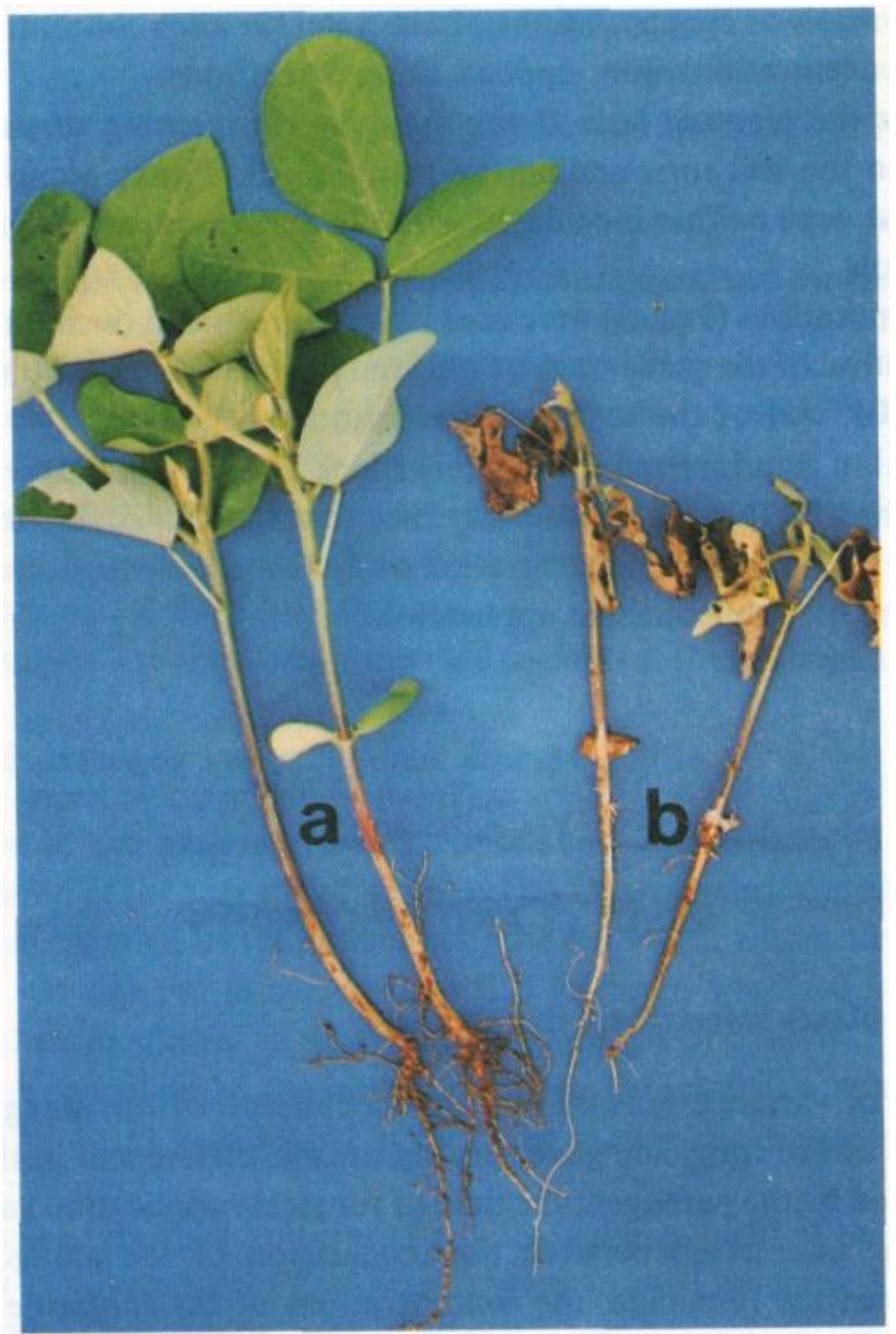

Figure 1. Non-infected (a) and infected (b) plants by Sclerotium rolfsii 14 DAP 
Possibility of controlling Sclerotium rolfsii on soybean - Okky S. Dharmaputra and Ina Retnowati

Table 1. Analysis of variance on the effect of Trichoderma aureoviride BIO-5, Tebuconazole and the time of fungicide application on the percentage of plants infected by Sclerotium rolfsii

\begin{tabular}{ccrrc}
\hline \hline Source of var. & Df & \multicolumn{1}{c}{ SS } & MS & F-value \\
\hline A & 1 & 4646.688 & 4646.688 & $35.840^{* *}$ \\
C & 2 & 4624.055 & 2312.027 & $17.833^{* *}$ \\
T & 1 & 774.688 & 774.688 & $5.975^{*}$ \\
A x C & 2 & 334.068 & 167.031 & 1.288 \\
C x T & 2 & 438.391 & 219.195 & 1.691 \\
A x C X T & 2 & 11.047 & 5.523 & 0.043 \\
Block & 2 & 30.383 & 15.191 & 0.117 \\
\hline
\end{tabular}

\begin{tabular}{|c|c|}
\hline A & $=$ the antagonist \\
\hline $\mathrm{C}$ & $=$ the concentrations of the fungicide \\
\hline $\mathbf{T}$ & $=$ the time of fungicide application \\
\hline $\mathrm{A} \times \mathrm{C}$ & $=$ the interaction between the antagonist and the concentrations of the fungicide \\
\hline $\mathrm{C} \times \mathrm{T}$ & $\begin{array}{l}=\text { the interaction between the concentrations of the fungicide and the time of fungicide } \\
\text { application }\end{array}$ \\
\hline$A \times C \times T$ & $\begin{array}{l}=\text { the interaction among the antagonist, the concentrations of the fungicide and the time } \\
\text { of fungicide application }\end{array}$ \\
\hline * & $=$ significantly different at $95 \%$ confidence level \\
\hline ** & $=$ very significantly different at $99 \%$ confidence level \\
\hline
\end{tabular}

Table 2. The effect of the inoculation of Trichoderma aureoviride BIO-5, the concentrations of Tebuconazole and the time of fungicide application on the percentage of plants infected by Sclerotium rolfsii

\begin{tabular}{lc}
\hline \hline Effect & Percentage of infected plants*) \\
\hline$T$. aureoviride BIO-5 & $34.1 \mathrm{a}$ \\
Inoculated & $56.8 \mathrm{~b}$ \\
Not inoculated & \\
Concentrations of Tebuconazole (g/ha) & $61.5 \mathrm{c}$ \\
0 & $37.5 \mathrm{~d}$ \\
100 & $37.4 \mathrm{~d}$ \\
210 & \\
Time of fungicide application & \\
At the same day with the & \\
$\quad$ planting of soybean seeds & $40.8 \mathrm{e}$ \\
7 days after planting & $50.1 \mathrm{f}$ \\
\hline
\end{tabular}

") Numbers followed by the same letter do not differ significantly according to DMR Test at $95 \%$ confidence level 
seeds $(40.8 \%)$ than when the fungicide was applied 7 DAP (50.1\%) (Table 2). It was assumed that the plants were already infected by the pathogen before spraying.

It is interesting to note that the percentage of infected plants on soil sprayed with the fungicide at in vitro concentration combined with the inoculation of the antagonist $\left(\mathrm{SFT}_{1} \mathrm{~A}_{1}=20 \%\right)$ was lower than on soil sprayed with the fungicide at field concentration $\left(\mathrm{SF}_{2} \mathrm{~T}_{0} \mathrm{~A}=35.3 \%\right.$ ) (Table 3$)$, but based on statistical analysis the interaction among the inoculation of the antagonist, the concentrations of the fungicide and the time of fungicide application did not give any significant difference (Table 1).

Figure 2 shows the plants on soil inoculated with the pathogen 14 DAP; while Figure 3 shows the plants inoculated with the pathogen and sprayed with the fungicide at field concentration $(210 \mathrm{~g} / \mathrm{ha})$ at the same day of seed planting.

The plants on soil inoculated with the pathogen, sprayed with the fungicide at concentration of $100 \mathrm{~g} / \mathrm{ha}$ (in vitro concentration) at the same day of seed planting, and inoculated with the antagonist is presented in Figure 4.

According to Upadhyay and Mukhodhyay (1986), a combination of PCNB with $T$. harzianum was able to control basal stem rot in sugar beet caused by $S$. rolfsii up to $76 \%$.

\section{Seed production}

Analysis of variance showed that the inoculation of the antagonist and the concentrations of the fungicide gave very significant differences in seed production; the time of fungicide application gave significant difference. The interaction between the inoculation of the antagonist and the concentrations of the fungicide; the concentrations of the fungicide and the time of fungicide application, and among the inoculation of the antagonist, the concentrations of the fungicide and the time of fungicide application did not give any significant differences (Table 4).

The seed production of the soil inoculated with the antagonist was higher and significantly different $(1863.3 \mathrm{~kg} / \mathrm{ha})$ than that of the soil not inoculated with the antagonist (1351.8 kg/ha) (Table 5).

According to Elad et al. (1980) T. harzianum was able to control the disease on bean, cotton or tomato caused by $S$. rolfsii and Rhizoctonia solani. The antagonist was also able to increase the production of bean.

The soybean production of the soil sprayed with the fungicide either at in vitro concentration $(1758.0 \mathrm{~kg} / \mathrm{ha})$ or at field concentration $(1817.1 \mathrm{~kg} / \mathrm{ha})$ was significantly different from that not sprayed with the fungicide (1247.2 kg/ha) (Table 5). Nevertheless, the soybean production of the soil sprayed with fungicide at field concentration was higher than that of the soil sprayed with the fungicide at in vitro concentration. 
Possibility of controlling Sclerotium rolfsii on soybean - Okky S. Dharmaputra and Ina Retnowati

Table 3. Percentage of soybean plants infected by Sclerotium rolfsii with different treatments

\begin{tabular}{lc}
\hline Treatment & Percentage of infected plants \\
\hline $\mathrm{SF}_{0} \mathrm{~T}_{0}$ & 76.3 \\
$\mathrm{SF}_{0} \mathrm{~T}_{1}$ & 46.7 \\
$\mathrm{SF}_{1} \mathrm{~T}_{0} \mathrm{~A}$ & 44.0 \\
$\mathrm{SF}_{2} \mathrm{~T}_{0} \mathrm{~A}$ & 35.3 \\
$\mathrm{SF}_{1} \mathrm{~T}_{1} \mathrm{~A}$ & 20.0 \\
$\mathrm{SF}_{2} \mathrm{~T}_{1} \mathrm{~A}$ & 22.7 \\
$\mathrm{SF}_{1} \mathrm{~T}_{0} \mathrm{~B}$ & 54.7 \\
$\mathrm{SF}_{2} \mathrm{~T}_{0} \mathrm{~B}$ & 54.3 \\
$\mathrm{SF}_{1} \mathrm{~T}_{1} \mathrm{~B}$ & 31.3 \\
$\mathrm{SF}_{2} \mathrm{~T}_{1} \mathrm{~B}$ & 37.3 \\
\hline $\mathrm{S}=$ soil inoculated with $S$. rolfsii & \\
$\mathrm{F}_{0}=$ soil not sprayed with $\mathrm{Tebuconazole}$ & \\
$\mathrm{F}_{1}=$ soil sprayed with $\mathrm{Tebuconazole}$ at in vitro concentration $(100 \mathrm{~g} / \mathrm{ha})$ \\
$\mathrm{F}_{2}=$ soil sprayed with $\mathrm{Tebuconazole}$ at field concentration $(210 \mathrm{~g} / \mathrm{ha})$ \\
$\mathrm{T}_{0}=$ soil not inoculated with $T$. aureoviride $\mathrm{BIO}-5$ \\
$\mathrm{~T}_{1}=$ soil inoculated with $T$. aureoviride BIO-5 \\
$\mathrm{A}=$ soil sprayed with the fungicide at the time of planting \\
$\mathrm{B}=$ soil sprayed with the fungicide 7 days after planting
\end{tabular}

Table 4. Analysis of variance on the effect of Trichoderma aureoviride BIO-5, Tebuconazole and the time of fungicide application on the production of soybean seeds

\begin{tabular}{ccrrr}
\hline \hline Source of var. & Df & \multicolumn{1}{c}{ SS } & MS & \multicolumn{1}{c}{ F-value } \\
\hline A & 1 & 2351724.484 & 2351724.484 & $15.09^{* *}$ \\
C & 2 & 2356997.985 & 1178498.992 & $7.56^{* *}$ \\
T & 1 & 798401.818 & 798401.818 & $5.12^{*}$ \\
A x C & 2 & 963998.257 & 481999.129 & 3.09 \\
C X T & 2 & 640121.791 & 320060.895 & 2.05 \\
A x C X T & 2 & 111343.352 & 55671.676 & 0.36 \\
Block & 2 & 264768.500 & 132384.250 & 0.85 \\
\hline
\end{tabular}

\footnotetext{
A $\quad=$ the antagonist

C = the concentrations of the fungicide

$\mathrm{T} \quad=$ the time of fungicide application

$\mathrm{A} \times \mathrm{C}=$ the interaction between the antagonist and the concentrations of the fungicide

$\mathrm{C} \times \mathrm{T}=$ the interaction between the concentrations of the fungicide and the time of fungicide application

A $\times \mathrm{C} \times \mathrm{T}=$ the interaction among the antagonist, the concentrations of the fungicide and the time of fungicide application

- $=$ significantly different at $\mathbf{9 5 \%}$ confidence level

** $\quad=$ very significantly different at $99 \%$ confidence level
} 


\section{BIOTROPIA No. 7, 1994}

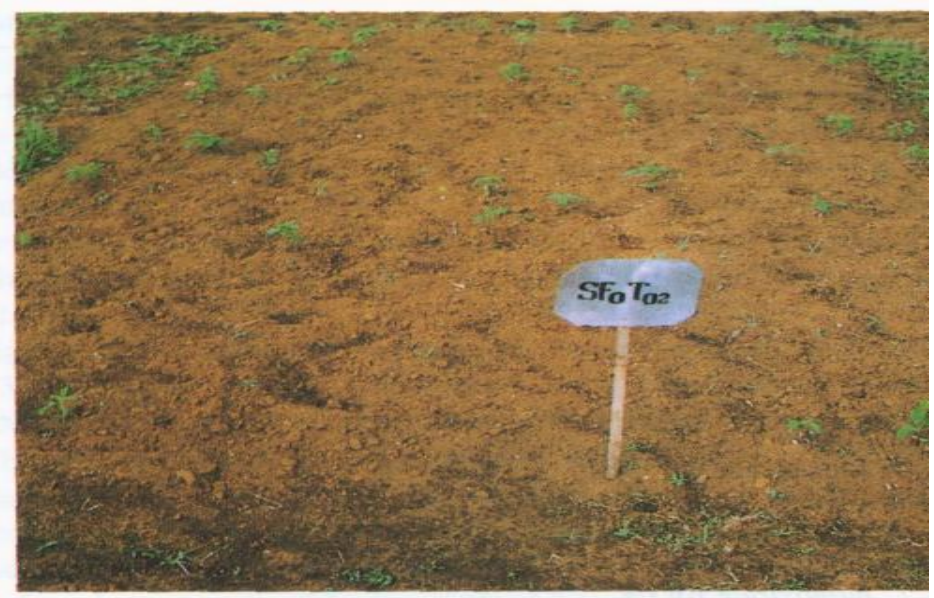

Figure 2. Soybean plants on soil inoculated with Sclerotium rolfsii, 14 DAP

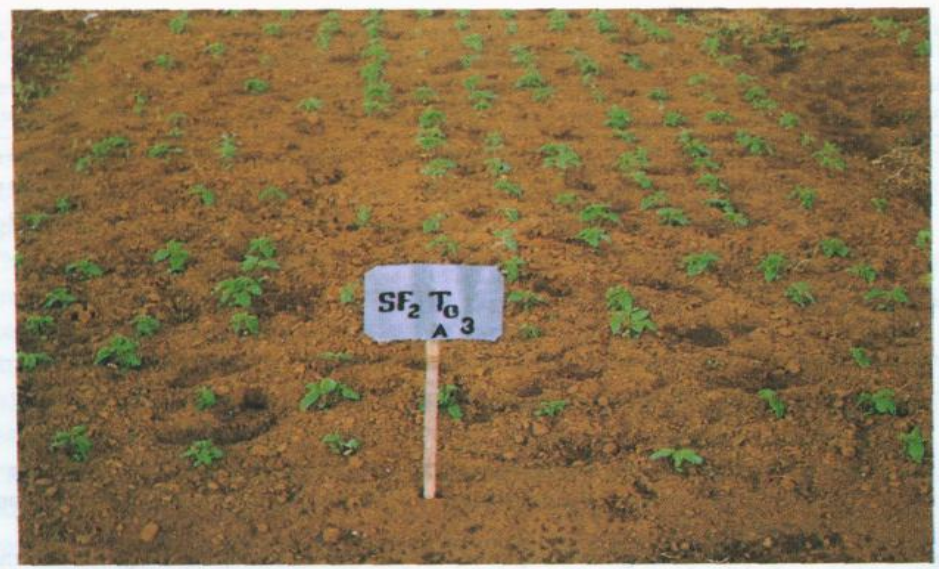

Figure 3. Soybean plants (14 days after planting) on soil inoculated with Sclerotium rolfsii and sprayed with Tebuconazole at concentration of $210 \mathrm{~g} / \mathrm{ha}$ at the same day of seed planting 


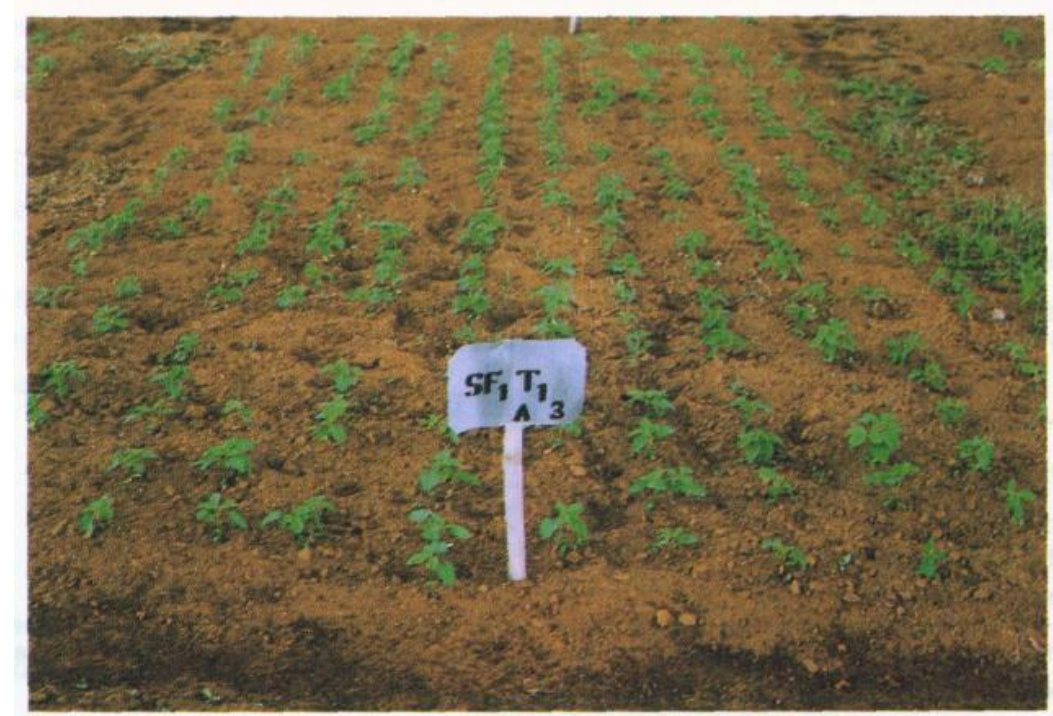

Figure 4. Soybean plants (14 DAP) on soil inoculated with Sclerotium rolfsii and TricHoderma aure-oviride BIO-5, and sprayed with Tebuconazole at concentration of $100 \mathrm{~g} / \mathrm{ha}$ at the same day of seed planting

The soybean production of the soil sprayed with the fungicide at the same day with the planting of seeds was higher and significantly different $(1756.3 \mathrm{~kg} / \mathrm{ha})$ than that of the soil sprayed with the fungicide 7 DAP $(1458.5 \mathrm{~kg} / \mathrm{ha})$ (Table 5).

The combination of inoculation of the antagonist, and fungicide application at in vitro concentration at the same day as the planting of soybean seeds $\left(\mathrm{S}_{1} \mathrm{~F}_{1} \mathrm{~T}_{1} \mathrm{~A}=2391.2\right.$ $\mathrm{kg} / \mathrm{ha})$ gave higher soybean production than inoculation of the antagonist $\left(\mathrm{S}_{1} \mathrm{~F}_{0} \mathrm{~T}_{1}=1711.7\right.$ $\mathrm{kg} / \mathrm{ha})$ or the fungicide application either at in vitro concentration $\left(\mathrm{S}_{1} \mathrm{~F}_{1} \mathrm{~T}_{0} \mathrm{~A}=1771.9\right.$ $\mathrm{kg} / \mathrm{ha})$ or at field concentration $\left(\mathrm{S}_{1} \mathrm{~F}_{2} \mathrm{~T}_{0} \mathrm{~A}=1939.1 \mathrm{~kg} / \mathrm{ha}\right)($ Table 6), but based on statistical analysis the interaction among the inoculation of the antagonist, the concentrations of the fungicide and the time of fungicide application did not give any significant difference (Table 4). 
Table 5. The effect of the inoculation of Trichoderma aureoviride BIO-5, the concentrations of

Tebuconazole and the time of fungicide application on the production of soybean seeds

\begin{tabular}{lc}
\hline \hline Effect & Seed production $\left.(\mathrm{kg} / \mathrm{ha})^{*}\right)$ \\
\hline $\begin{array}{l}\text { T. aureoviride BIO-5 } \\
\text { Not inoculated }\end{array}$ & $1351.8 \mathrm{a}$ \\
Inoculated & $1863.0 \mathrm{~b}$ \\
Concentrations of Tebuconazole $(\mathrm{g} / \mathrm{ha})$ & $1247.2 \mathrm{c}$ \\
0 & $1758.0 \mathrm{~d}$ \\
100 & $1817.1 \mathrm{~d}$ \\
210 & \\
Time of fungicide application & $1458.5 \mathrm{e}$ \\
7 days after planting & $1756.3 \mathrm{f}$ \\
At the same day with the & \\
$\quad$ planting of soybean seeds & \\
\hline
\end{tabular}

*) Numbers followed by the same letter do not differ significantly according to DMR Test at $95 \%$ confidence level

Table 6. The production of soybean seeds with different treatments

\begin{tabular}{lc}
\hline \hline Treatment*) & Seed production $(\mathrm{kg} / \mathrm{ha})$ \\
\hline $\mathrm{S}_{1} \mathrm{~F}_{0} \mathrm{~T}_{0}$ & 782.6 \\
$\mathrm{~S}_{1} \mathrm{~F}_{0} \mathrm{~T}_{1}$ & 1711.7 \\
$\mathrm{~S}_{1} \mathrm{~F}_{1} \mathrm{~T}_{0} \mathrm{~A}$ & 1771.9 \\
$\mathrm{~S}_{1} \mathrm{~F}_{2} \mathrm{~T}_{0} \mathrm{~A}$ & 1939.1 \\
$\mathrm{~S}_{1} \mathrm{~F}_{1} \mathrm{~T}_{1} \mathrm{~A}$ & 2391.2 \\
$\mathrm{~S}_{1} \mathrm{~F}_{2} \mathrm{~T}_{1} \mathrm{~A}$ & 1941.5 \\
$\mathrm{~S}_{1} \mathrm{~F}_{1} \mathrm{~T}_{0} \mathrm{~B}$ & 1269.5 \\
$\mathrm{~S}_{1} \mathrm{~F}_{2} \mathrm{~T}_{0} \mathrm{~B}$ & 1565.2 \\
$\mathrm{~S}_{1} \mathrm{~F}_{1} \mathrm{~T}_{1} \mathrm{~B}$ & 1599.3 \\
$\mathrm{~S}_{1} \mathrm{~F}_{2} \mathrm{~T}_{1} \mathrm{~B}$ & 1822.6 \\
\hline${ }^{*} \mathrm{~S}_{1}=$ soil inoculated with $S$. rolfsii & \\
$\mathrm{F}_{0}=$ soil not sprayed with Tebuconazole & \\
$\mathrm{F}_{1}=$ soil sprayed with Tebuconazole at in vitro concentration $(100 \mathrm{~g} / \mathrm{ha})$ \\
$\mathrm{F}_{2}=$ soil sprayed with Tebuconazole at field concentration $(210 \mathrm{~g} / \mathrm{ha})$ \\
$\mathrm{T}_{0}=$ soil not inoculated with $T$. aureoviride BIO-5 \\
$\mathrm{T}_{1}=$ soil inoculated with $T$. aureoviride BIO-5 \\
$\mathrm{A}=$ soil sprayed with the fungicide at the same day of seed planting \\
$\mathrm{B}=$ soil sprayed with the fungicide 7 days after planting
\end{tabular}


Possibility of controlling Sclerotium rolfsii on soybean - Okky S. Dharmaputra and Ina Retnowati

\section{CONCLUSIONS}

T. aureoviride BIO-5 or Tebuconazole could be used to control S. rolfsii. They also could increase seed production. The fungicide was more effective when applied at the same day of seed planting than at 7 DAP.

The use of the fungicide at in vitro concentration combined with the use of the antagonist was more effective in decreasing the percentage of infected plants and increasing the seed production than the use of the fungicide at field concentration at the same day of seed planting.

\section{ACKNOWLEDGEMENT}

The authors gratefully acknowledge the financial support of the Government of Indonesia. Thanks are due to the technicians of the Laboratory of Plant Pathology, SEAMEO BIOTROP.

\section{REFERENCES}

AGRIOS, G.N. 1988. Plant Pathology. Academic Press, New York.

BAYER. 1990. Folicur; Systemisches Fungizid Technische Information.

COLE, J.S. and Z. ZVENYIKA. 1988. Integrated control of Rhizoctonia solani and Fusarium solani in tobacco transplants with Trichoderma harzianum and triadimenol. Plant Pathology 37: 271-277.

COOK, R. J. and K.F. BAKER. 1983. The Nature and Practice of Biological Control of Plant Pathogens.

The American Phytopathological Society, St. Paul, Minnesota.

DHARMAPUTRA, O.S. and W.P. SUWANDI. 1989. Substrat untuk produksi besar-besaran Trichoderma.

(Substrate for mass production of Trichoderma). Annual Report. Research collaboration between

Marihat Research Centre and BIOTROP. BIOTROP/TAgR/89/736: 44-52.

DHARMAPUTRA, O.S. and I. RETNOWATI. 1992. The possibility of controlling Sclerotium rolfsii on soybean (Glycine max) using Trichoderma, Gliocladium and Tebuconazole. SEAMEO BIOTROP. Internal Report.

ELAD, Y., I. CHET and J. KATAN. 1980. Trichoderma harzianum: A biocontrol agent effective against Sclerotium rolfsii and Rhizoctonia solani. Phytopathology 70: 119-121.

PAPAVIZAS, G.C. and J.A. LEWIS. 1989. Effect of Gliocladium and Trichoderma on damping-off and blight of snapbean caused by Sclerotium rolfsii in the greenhouse. Plant Pathology 38: 277-286.

RIKER, A.J. and R.S. RIKER. 1936. Introduction to Research and Plant Diseases. John Swift and Co., St. Louis. Mo.

SINAGA, M.S. 1986. Biological control of some soil-borne fungal pathogens of soybean (Glycine max (L.) Merr.) with Gliocladium spp. Ph.D. thesis. University of the Philippines at Los Banos.

SIVAN, A., Y. ELAD and I. CHET. 1984. Biological control effects of a new isolate of Trichoderma harzianum on Pythium aphanidermatum. Phytopathology 74: 498-501.

UPADHYAY, J.P. and A.N. MUKHOPADHYAY. 1986. Biological control of Sclerotium rolfsii by Trichoderma harzianum in sugar beet. Trop. Pest Management 32: 215-220. 